\title{
THE EFFECT OF POLLINATING INSECTS ON FRUITING OF TWO CULTIVARS OF Lonicera caerulea $\mathrm{L}$.
}

\author{
Malgorzata Bożek \\ Department of Botany, University of Life Sciences in Lublin, \\ Akademicka 15, 20-950 Lublin, Poland \\ e-mail: malgorzata.bozek@up.lublin.pl
}

Received 03 January 2012; accepted 04 October 2012

$\mathrm{S} \mathrm{u} \mathrm{m} \mathrm{m} \mathrm{a} \mathrm{r} \mathrm{y}$

In 2004 and 2006-2008, a study was conducted on the effect of pollinating insects on the fruit, seed set, and development of two cultivars of blue honeysuckle Lonicera caerulea (Sevast.) Pojark.: "Atut" and "Duet". The experiment was carried out in south-eastern Poland, at the Experimental Farm of the University of Life Sciences in Lublin, Poland. Flowers accessible to pollinating insects throughout the whole flowering period, set fruit at a very high percentage. The study average was $90.57 \%$ for "Duet" and $88.08 \%$ for "Atut". During self-pollination under isolation, on the other hand, the percentage of fruit-bearing flowers was low. In the case of "Atut" the average was $9.37 \%$, whereas for "Duet" it was $23.85 \%$. Multiple fruits formed from isolated flowers had a $45-50 \%$ lower weight, on average, than those developed from flowers accessible to pollinating insects. The pollination mode was found to have a significant effect on the number of seeds produced in the multiple fruit. Flowers which were isolated to prevent insect foraging did develop multiple fruits, characterized by a significantly lower number of seeds. The recent studies confirm that several cultivars should be planted on honeysuckle acreage. The presence of managed pollinators can increase quantity and improve quality of fruit yield in honeysuckle.

Keywords: Lonicera caerulea, honeysuckle, open pollination, self-pollination, fructification.

\section{INTRODUCTION}

The genus Lonicera (f. Caprifoliaceae) has approximately 180 species, including shrubs with climbing or non-climbing stems. A few species, such as Lonicera caerulea L. commonly called blue honeysuckle or blue-berried honeysuckle, produce edible fruits which ripen very early. The systematic position of $L$. caerulea is complicated, since a lot of cultivars are sometimes classified as species and have many synonyms (Naugžemys et al., 2007; USDA, 2010). A characteristic feature of $L$. caerulea is a double-flower inflorescence. The inferior ovaries of both flowers are aggregated by sepalous leaves which form a homogenous, fleshy coating of the multiple fruit (Rośliny kwiatowe, 1998). The ripe multiple fruit consists of two false berries and looks like a single berry. Sweet enough to be eaten fresh, the berries can also be made into jam, jelly, and even ice cream. Any surplus fruits will retain their flavour and shape when frozen.

Fruits are an excellent source of dietary phytochemicals (anthocyanins, polyphenolics, and ascorbic acid) and can be used as natural colorants (Oszmiański et al., 1995; Thompson and Chaovanalikit, 2003; Skupień et al., 2007; Małodobry et al., 2010). They may provide protection against a number of chronic conditions, e.g. cancer, diabetes mellitus, tumour growth or cardiovascular diseases (Svarcova et al., 2007).

Blue honeysuckle shrubs can be grown with success throughout Poland. They are very frost hardy, as the plants are not damaged even if the temperature drops below $-40^{\circ} \mathrm{C}$. Open flowers can withstand freezing temperatures to $-8^{\circ} \mathrm{C}$ (Plekhanova, 2000). Blue honeysuckles 
are not self-pollinated, so at least two single plants (different cultivars) are required. In Poland, flowers are visited by honey bees, bumblebees, and solitary bees which gather pollen and nectar (Bożek and Wieniarska, 2006; Bożek, 2007). The fruits of blue honeysuckle, depending on the cultivar, ripen from the end of May till June.

The aim of the present study was to determine the degree of fruit set, the weight, and dimensions of multiple fruits as well as the number of seeds, all determined under isolation conditions and with free insect visitation of the flowers of two Lonicera caerulea cultivars: "Atut" and "Duet".

\section{MATERIALS AND METHODS}

Observations were carried out in 2004, 2006, 2007, and 2008 in south-eastern Poland, at the Experimental Farm of the University of Life Sciences in Lublin. Two Polish bred cultivars of blue honeysuckle, "Atut" and "Duet", were tested. The multiple fruits of these cultivars are bigger and more tasty when compared with the Russian cultivars such as "Czelabinka" and "Sinogłazka". The shrubs were planted in a strip-plot design in two rows in the spring of 2001. The distance between the plants in the row was $1 \mathrm{~m}$, whereas the distance between the strips was $1.2 \mathrm{~m}$. The experiment was established on greybrown podzolic soil derived from medium loams. The soil mechanical composition corresponded to light silty loams with a slightly acidic $\mathrm{pH}$.

To determine the effect of the pollination mode on fruit and seed set and development, eight shrubs of each cultivar were selected. Before flowering, four stems were marked on each shrub: chiffon covers were put on two stems, while the other two stems remained accessible to pollinating insects throughout the entire flowering period. Due to the gradual appearance of new flower buds, opening flowers were counted on the marked stems several times during the flowering period. The corollas were marked with a water-resistant marker. During ripening, the fruits were harvested several times and counted. Each fruit was weighed individually. Fruit length and width were measured (the longer crosssectional axis) with an electronic calliper. After taking the measurements, the fruits of each shrub were frozen separately according to fruits which developed from isolated flowers or fruit which developed from flowers freely accessible to pollinating insects. Ten multiple fruits were randomly selected from each sample and the seeds were taken from them. After drying the seeds at room temperature, they were counted and weighed. The percentage of fruit set was determined in 2004, 2006, and 2007. Fruit weight and fruit dimensions were determined in 2004, and 2006 - 2008, while the number and weight of seeds in 2006 - 2008.

Mean values of air temperature and total precipitation in 2004, and 2006-2008, relative to the long-term mean for 19512005, are given in Table 1. These data were obtained from the weather station of the University of Life Sciences located in the district of Felin in Lublin.

The results were statistically analysed with a three-way ANOVA analysis, and a post-hoc Tukey's test at $\alpha=0.05$ was used (STATISTICA v. 7.1). The data on fruit set were transformed according to $\arcsin \left(\mathrm{x}^{0.05}\right)$ to improve normality.

\section{RESULTS AND DISCUSSION}

The observations covered four years. In 2007, the cultivars under study began flowering earliest (12 April). From the beginning of 2007, the air temperatures were much higher than normal (Tab. 1) which clearly accelerated the growth of the plants. The cultivars bloomed latest (1 May) in 2006, when in the first three months (January, February, March) much lower temperatures were recorded compared to the long-term mean. In 2008, the onset of flowering was recorded on 17 April, and in 2004 on 20 April. The end of the flowering period of these plants was between the middle of May and the $20^{\text {th }}$ of May. The first fruits were harvested earliest in 2007, from 28 May to 14 June. 
In 2004, the harvest lasted from 4 June to 18 June, in 2006 from 8 June to 26 June, and in 2008 between 11 and 24 June. During the flowering period, flowers of the studied cultivars were visited by numerous honey bees, bumblebees, and solitary bees. Honey bee workers gathered both nectar and pollen.

When analysing the number of fruit set compared to the number of flowers, there were significant effects of the following factors: cultivar $\mathrm{x}$ isolation $\left(\mathrm{F}_{3,92}=299.8037, \mathrm{P}=0.0000\right)$, cultivar $\mathrm{X}$ isolation $\mathrm{x}$ years $\left(\mathrm{F}_{11,84}=105.1508\right.$, $\mathrm{P}=0.0000)$. Flowers accessible to pollinating insects throughout the entire flowering period, set fruit at a high percentage - $90.57 \%$, on average, for "Duet", and 88.08\% for "Atut" (Tab. 2). When self-pollinated under isolation, the percentage of fruit-bearing flowers averaged only $9.37 \%$ for "Atut", while for "Duet" it was $23.85 \%$. A trend towards a lower percentage of fruit set was observed for both cultivars in 2006 and 2007 (but without any significant statistical differences). Mean monthly temperatures were higher than the long-term averages during flowering of the plants (April, May).

The fruit mass of the studied blue honeysuckle cultivars depended on cultivar $\mathrm{x}$ pollination mode $\mathrm{x}$ year $\left(\mathrm{F}_{3,112}=4.513\right.$,

Table 1 .

Mean values of air temperature and total precipitation in 2004, 2006-2008 relative to the long-term mean for 1951-2005. Date from the Felin weather station in Lublin

\begin{tabular}{||l|c|c|c|c|c|c|c|c|c|c|c|c||}
\hline \multirow{2}{*}{ Year } & \multicolumn{10}{|c||}{ Months } \\
\cline { 2 - 13 } & I & II & III & IV & V & VI & VII & VIII & IX & X & XI & XII \\
\hline Mean monthly air temperature in ${ }^{\circ} \mathrm{C}$ \\
\hline 2004 & -5.6 & -1.0 & 2.8 & 7.9 & 11.9 & 15.8 & 18.1 & 18.3 & 13.8 & 9.8 & 3.1 & 1.5 \\
2006 & -7.6 & -4.3 & -1.0 & 8.7 & 13.6 & 16.9 & 21.9 & 17.4 & 15.7 & 10.1 & 5.3 & 3.0 \\
2007 & 2.6 & -1.6 & 6.2 & 8.7 & 15.0 & 18.1 & 19.2 & 18.4 & 13.0 & 7.1 & 1.0 & -1.2 \\
2008 & 0.4 & 2.2 & 3.4 & 9.3 & 12.8 & 17.7 & 18.3 & 19.3 & 12.6 & 10.1 & 4.8 & -0.9 \\
\hline Long-term mean & -3.6 & -2.9 & 1.0 & 7.5 & 13.0 & 16.2 & 17.8 & 17.2 & 12.6 & 7.9 & 2.5 & -1.3 \\
\hline Monthly total precipitation in & \multicolumn{10}{|c||}{} \\
\hline 2004 & 32.7 & 52.5 & 33.9 & 38.1 & 38.0 & 49.9 & 90.5 & 48.5 & 14.2 & 19.1 & 58.2 & 17.1 \\
2006 & 15.7 & 26.7 & 47.0 & 30.3 & 59.3 & 37.9 & 6.8 & 198.3 & 11.0 & 14.2 & 41.2 & 18.6 \\
2007 & 51.5 & 22.3 & 30.2 & 17.4 & 81.5 & 87.8 & 87.0 & 37.6 & 129.8 & 17.7 & 31.1 & 14.9 \\
2008 & 36.2 & 17.8 & 64.8 & 55.8 & 101.6 & 25.9 & 77.1 & 45.0 & 102.2 & 55.5 & 33.9 & 43.8 \\
\hline Long-term mean & 21.7 & 24.8 & 26.3 & 40.2 & 57.7 & 65.8 & 83.5 & 68.6 & 51.6 & 40.1 & 39.1 & 31.5 \\
\hline
\end{tabular}

Table 2 .

Percentage of blue honeysuckle fruits obtained from open-pollinated and isolated flowers (mean values are given)

\begin{tabular}{||c|c|c|c||}
\hline \multirow{2}{*}{ Cultivar } & \multirow{2}{*}{ Year } & \multicolumn{2}{|c|}{ Percentage of flowers setting fruits* } \\
\cline { 3 - 4 } & & non isolated & isolated \\
\hline \multirow{4}{*}{ Atut } & 2004 & $96.05^{\mathrm{a}}$ & $16.38^{\mathrm{de}}$ \\
\cline { 2 - 4 } & 2006 & $80.05^{\mathrm{ab}}$ & $9.82^{\mathrm{de}}$ \\
\cline { 2 - 4 } & 2007 & $88.15^{\mathrm{a}}$ & $1.91^{\mathrm{e}}$ \\
\cline { 2 - 4 } & mean & $88.08^{\mathrm{A}}$ & $9.37^{\mathrm{C}}$ \\
\hline \multirow{4}{*}{ Duet } & 2004 & $95.56^{\mathrm{a}}$ & $23.76^{\text {cd }}$ \\
\cline { 2 - 4 } & 2006 & $90.36^{\mathrm{a}}$ & $33.03^{\text {cd }}$ \\
\cline { 2 - 4 } & 2007 & $85.80^{\mathrm{a}}$ & $14.75^{\mathrm{de}}$ \\
\cline { 2 - 4 } & mean & $90.57^{\mathrm{A}}$ & $23.85^{\mathrm{B}}$ \\
\hline
\end{tabular}

*data were transformed according to $\arcsin (\mathrm{x} 0.05)$ to improve normality;

Mean followed by the same letter are not significantly different at $\alpha=0.05$ (Tukey's test); the analysis concern differences between types of pollination (capital letters) and between years of study (small letters) within types of pollination. 
$\mathrm{P}=0.005)$ (Tab. 3). The cultivar "Duet" produced multiple fruits of higher mass (by about 20\%) from flowers both freely visited by pollinating insects and from isolated flowers. The average mass of the "Duet" cultivar's multiple fruit, produced with open pollination, was $1128.21 \mathrm{mg}$, while for "Atut", it was $891.68 \mathrm{mg}$. The average mass of the fruit produced under isolation was $582.64 \mathrm{mg}$ for "Duet" and $482.83 \mathrm{mg}$ for "Atut". In the case of open pollination, Małodobry et al. (2010) also observed slightly larger fruits in "Duet" (from 1.6 to $1.9 \mathrm{~g})$ than in "Atut" (0.8 - $1.06 \mathrm{~g})$. In 2004, fruits of both cultivars produced with open pollination, had a smaller mass (these differences were significant for "Atut"). Smaller mass was probably associated with lower temperatures and rainfall (relative to the long-term mean) during fruit development (May 2004) (Tab. 1). Szot and Wieniarska (2012) reported that qualitative traits of honeysuckle fruit are strongly dependent on weather conditions prevailing in a particular growth season.

Differences in fruit length were found between cultivars $\left(F_{1112)}=24.85\right.$, $\mathrm{P}=0.0000)$, and within the cultivars, between years and pollination modes $\left(\mathrm{F}_{3,112)}=11.12, \mathrm{P}=0.0000\right)$. The cultivar
"Atut" produced longer fruits - $16.91 \mathrm{~mm}$ when allowed free insect visitation and this cultivar produced $14.23 \mathrm{~mm}$ fruits, with flower isolation (Tab. 3). The cultivar "Duet" showed results of $15.91 \mathrm{~mm}$ when allowed free insect visitation and $13.14 \mathrm{~mm}$ with flower isolation. As far as fruit width (the longer cross-sectional axis) was concerned, significant differences were found between cultivars $\left(\mathrm{F}_{1,112}=46.01\right.$, $\mathrm{P}=0.0000)$, cultivars $\mathrm{x}$ pollination mode $\left(\mathrm{F}_{1,112}=4.39, \mathrm{P}=0.0384\right)$ as well as within the cultivars between years and pollination modes $\left(\mathrm{F}_{2112}=6.98, \mathrm{P}=0.0003\right)$. The cultivar "Duet" produced wider fruits (the longer cross-sectional axis), on average, by $10.9 \mathrm{~mm}$ with free insect visitation and by $8.47 \mathrm{~mm}$ under isolation, while for "Atut" these values were determined to be $9.87 \mathrm{~mm}$ and $7.93 \mathrm{~mm}$, respectively. Comparing the shape of the multiple fruit of both cultivars, "Atut" produced longer fruit, narrowing at the end, whereas the fruit of "Duet" was barrel-shaped.

In the case of both cultivars, the multiple fruit formed from isolated flowers was nearly twice as low in weight and was characterized by smaller dimensions. These features are in agreement with the reports of many authors relating to the

Table 3 .

Mass and size of blue honeysuckle multiple fruits obtained from free-pollinated and isolated flowers (mean values are given)

\begin{tabular}{|c|c|c|c|c|c|c|c|}
\hline \multirow{3}{*}{ Cultivar } & \multirow{3}{*}{ Year } & \multirow{2}{*}{\multicolumn{2}{|c|}{ Mass of 1 multiple fruit (mg) }} & \multicolumn{4}{|c|}{ Size of 1 multiple fruit (mm) } \\
\hline & & & & \multicolumn{2}{|c|}{ lenght } & \multicolumn{2}{|c|}{ diameter* } \\
\hline & & non isolated & isolated & non isolated & isolated & non isolated & isolated \\
\hline \multirow{5}{*}{ "Atut" } & 2004 & $697.13^{\text {cd }}$ & $540.39^{\text {de }}$ & $14.86^{d}$ & $14.01^{\mathrm{de}}$ & $8.82^{e-g}$ & $7.60^{\mathrm{hi}}$ \\
\hline & 2006 & $967.34^{b}$ & $536.38^{\text {de }}$ & $18.00^{\mathrm{a}}$ & $15.80^{b-d}$ & $10.49^{b-d}$ & $8.29^{f-h}$ \\
\hline & 2007 & $902.74^{\mathrm{bc}}$ & $313.38^{e}$ & $16.99^{\mathrm{a}-\mathrm{c}}$ & $12.28^{\mathrm{ef}}$ & $9.38^{\mathrm{d}-f}$ & $6.49^{i}$ \\
\hline & 2008 & $999.50^{b}$ & $541.16^{\text {de }}$ & $17.78^{\mathrm{ab}}$ & $14.81^{\mathrm{d}}$ & $10.78^{b}$ & $9.32^{\mathrm{ef}}$ \\
\hline & mean & $891.68^{B}$ & $482.83^{\mathrm{D}}$ & $16.91^{\mathrm{A}}$ & $14.23^{\mathrm{C}}$ & $9.87^{\mathrm{B}}$ & $7.93^{\mathrm{D}}$ \\
\hline \multirow{5}{*}{ "Duet" } & 2004 & $937.45^{b}$ & $575.18^{d}$ & $14.04^{\text {de }}$ & $12.49^{\mathrm{e}}$ & $9.53^{c-e}$ & $8.30^{\text {f-h }}$ \\
\hline & 2006 & $1047.21^{b}$ & $644.92^{\mathrm{d}}$ & $15.65^{\mathrm{cd}}$ & $13.97^{\mathrm{de}}$ & $11.19^{\mathrm{ab}}$ & $9.23^{\text {ef }}$ \\
\hline & 2007 & $1104.27^{b}$ & $528.69^{\text {de }}$ & $15.36^{\mathrm{cd}}$ & $11.80^{f}$ & $10.66^{\mathrm{bc}}$ & $7.90^{\text {gh }}$ \\
\hline & 2008 & $1423.99^{a}$ & $581.75^{d}$ & $18.62^{a}$ & $14.31^{\mathrm{de}}$ & $12.22^{\mathrm{a}}$ & $8.45^{\mathrm{e}-h}$ \\
\hline & mean & $1128.21^{A}$ & $582.64^{C}$ & $15.91^{B}$ & $13.14^{\mathrm{D}}$ & $10.9^{A}$ & $8.47^{C}$ \\
\hline
\end{tabular}

Mean followed by the same letter are not significantly different at $\alpha=0.05$ (Tukey's test);

the analysis concern differences between types of pollination (capital letters)

and between years of study (small letters) within types of pollination;

*the longer cross-sectional axis. 
Table 4 .

Number and mass of blue honeysuckle seeds

from multiple fruits obtained from open- pollinated and isolated flowers

\begin{tabular}{||l|c|c|c|c|c|c|c||}
\hline \multirow{3}{*}{ Cultivar } & \multirow{3}{*}{ Year } & \multicolumn{2}{|c|}{$\begin{array}{c}\text { Number of seeds } \\
\text { per 1 multiple fruit }\end{array}$} & \multicolumn{2}{c||}{ Mass of 10 seeds (mg) } & \multicolumn{2}{c||}{$\begin{array}{c}\text { Mass of seeds in relation to } \\
\text { mass of multiple fruits (\%) }\end{array}$} \\
\cline { 3 - 8 } & & non isolated & isolated & non isolated & isolated & non isolated & isolated \\
\hline \multirow{4}{*}{ "Atut" } & 2006 & $22.18^{\mathrm{a}}$ & $3.59^{\mathrm{e}}$ & $15.9^{\mathrm{a}-\mathrm{c}}$ & $17.9^{\mathrm{a}-\mathrm{c}}$ & 3.65 & 1.20 \\
& 2007 & $20.22^{\mathrm{ab}}$ & $2.70^{\mathrm{e}}$ & $14.2^{\mathrm{c}}$ & $19.2^{\mathrm{ab}}$ & 3.18 & 1.65 \\
& 2008 & $19.50^{\mathrm{ab}}$ & $2.05^{\mathrm{e}}$ & $14.4^{\mathrm{a}}$ & $17.2^{\mathrm{a}-\mathrm{c}}$ & 2.81 & 0.65 \\
& mean & $20.63^{\mathrm{A}}$ & $2.75^{\mathrm{C}}$ & $14.8^{\mathrm{B}}$ & $18.1^{\mathrm{A}}$ & 3.21 & 1.17 \\
\hline \multirow{4}{*}{ "Duet" } & 2006 & $14.73^{\mathrm{cd}}$ & $4.45^{\mathrm{e}}$ & $16.8^{\mathrm{a}}$ & $19.3^{\mathrm{ab}}$ & 2.36 & 1.33 \\
& 2007 & $10.50^{\mathrm{d}}$ & $3.4^{\mathrm{e}}$ & $14.8^{\mathrm{a}}$ & $15.8^{\mathrm{bc}}$ & 1.41 & 0.97 \\
& 2008 & $15.69^{\mathrm{bc}}$ & $3.43^{\mathrm{e}}$ & $16.6^{\mathrm{a}}$ & $16.0^{\mathrm{a}}$ & 1.83 & 0.94 \\
\hline
\end{tabular}

Mean followed by the same letter are not significantly different at $\alpha=0.05$ (Tukey's test);

the analysis concern differences between types of pollination (capital letters)

and between years of study (small letters) within types of pollination.

effect of pollinating insects on fruiting of various orchard plants (Bożek, 2009; Bieniasz, 2007; Jabłoński et. al., 1983; Denisow, 2002, 2003, 2005).

The pollination mode was found to have a significant effect on the number of seeds per fruit in both cultivars $\left(\mathrm{F}_{3,92}=226.558\right.$, $\mathrm{P}=0.0000)$ (Tab. 4). On average, the multiple fruit formed from flowers freely accessible to pollinating insects in the cultivar "Atut" produced 20.63 seeds, while in "Duet" 13.64 seeds. The multiple fruit developed from flowers inaccessible to pollinators contained significantly fewer seeds; in the case of "Atut" it was 7.5 times fewer, while in the case of "Duet" 3.7 times fewer. For "Atut", the average mass per 10 seeds was $14.8 \mathrm{mg}$ for fruits formed under free insect visitation of the flowers and $18.1 \mathrm{mg}$ from isolated flowers, whereas the corresponding results for "Duet" were $16.1 \mathrm{mg}$ and $17.0 \mathrm{mg}$, respectively. Multiplying the average number of seeds by the mass of a single seed, it can be calculated that seeds accounted for $3.21 \%$ of the mass of the fresh fruit of the cultivar "Atut" and 1.87\% in "Duet", in the case of open pollination. In both cultivars, a significant increase in the weight of a single seed from the multiple fruit formed from isolated flowers $\left(\mathrm{F}_{3,92}=4.3314, \mathrm{P}=0.0067\right)$ was observed. A similar relationship was found by Denisow (2002) in the blackcurrant cultivars.

\section{CONCLUSIONS}

1. The present study shows that in the absence of pollinating insects, fruit set is very poor in the blue honeysuckle $9.37 \%$ for "Atut", and $23.85 \%$ for "Duet". But in the case of free insect visitation, the percentage of fruit set should be considered to be high (on average $89.33 \%$ for the cultivars).

2. The pollination mode affected fruit mass in the studied cultivars of Lonicera caerulea. The multiple fruits formed from isolated flowers of the blue honeysuckle "Atut" and "Duet" had a nearly twice lower mass compared to those developed from flowers freely visited by insects.

3. The multiple fruits developed from flowers isolated to prevent insect foraging were characterized by a significantly lower number of seeds.

4. The recent studies confirm that several cultivars should be planted for sufficient crop.

5. The presence of managed pollinators can increase quantity and improve quality of fruit yield in honeysuckle.

\section{REFERENCES}

Bożek M., Wieniarska J. (2006) - Biologia kwitnienia i wydajność cukrowa kwiatów dwóch odmian Lonicera kamtschatica (Sevast.) Pojark. Acta Agrobot., 59(1): 177-182. 
Bożek M. (2007) - Pollen productivity and morphology of pollen grains in two cultivars of honeyberry (Lonicera kamtschatica (Sevast.) Pojark). Acta Agrobot., 60(1): 73-77.

Bożek M. (2009) - Flowering and fruit set of six cultivars of highbush blueberry (Vaccinium corymbosum L.) in the conditions of the Lublin region. Acta Agrobot., 62(1): 91-96.

Bieniasz M. (2007) - Effects of open and self pollination of four cultivars of highbush blueberry (Vaccinium corymbosum L.) on flower fertilization, fruit set and seed formation. J. Fruit Ornam. Plant Res., 15: 35-40.

Denisow B. (2002) - The influence of the degree of pollination of black currant flowers (Ribes nigrum L.) on the number of seeds in fruits and its size. Annales UMCS, sect. EEE, 11: 11-18.

Denisow B. (2003) - Self-pollination and self-fertility in eight cultivars of black currant (Ribes nigrum L.). Acta Biol. Cracov. ser. Bot., 45(1): 111-114.

Denisow B. (2005) - The variability of yield structure of black currant cultivars (Ribes nigrum L.) in different pollination conditions. Apiacta [online] www.apimondia.org/apiacta/ slovenia.

Jabłoński B. Król S., Pliszka K., Żurowska Z. (1983) - Nektarowanie i zapylanie borówki wysokiej (Vaccinum corymbosum L.) /Nectar secretion and pollination of highbush blueberry (Vaccinum corymbosum L.). Pszczeln. Zesz. Nauk. XXVII: 91-109.

Małodobry M., Bieniarz M., Dziedzic E. (2010) - Evaluation of the yield and some components in the fruit of blue honeysuckle (Lonicera caerulea var. edulis Turcz. Freyn.). Folia Horticulturae Ann. 22(1): 45-50.

Naugžemys D., Žilinskaitė S., Denkovskij J., Patamsytė J., Literskis J., Žvingila D. (2007) RAPD based study of genetic variation and relationships among Lonicera germplasm accesions. Biologija, 53(3): 34-39.

Oszmiański J., Souquet J. M., Mountounet M. (1995) - Antocyjany owoców borówki kamczackiej. Zeszyty Naukowe AR, Wrocław, Technologia żywności VII, 23: 67-72.

Plekhanova M. N. (2000) - Blue Honeysuckle (Lonicera caerulea L.) - a new commercial berry crop for temperate climate: genetic resources and breeding. Acta Hort., 538: 159-164.

Rośliny kwiatowe, Wielka encyklopedia Przyrody (1998) - Muza S. A.: pp. 188-189.

Skupień K., Oszmiański J., Ochmian I., Grajkowski J. (2007) - Characterization of Selected Physico-Chemical Features of Blue Honeysuckle Fruit Cultivar 'Zielona'. Polish J. Nat. Sci., suppl., 4: 101-107.

Svarcova I., Heinrich J., Valentova K. (2007) - Berry fruits as a source of biologically active compounds: the case of Lonicera caerulea. Biomed Pap Med Fac Univ Palacky Olomouc Czech Republic, 151(2): 163-174.

Szot I., Wieniarska J. (2012) - Effect of Foliar Applications of Goëmar ${ }^{\mathbb{R}}$ BM 86 and Soil Applied Calcium Nitrate on Yield and Berry Quality of Two Blue Honeysuckle Cultivars. Acta Sci. Pol., Hortorum Cultus, 11(1): 133-144.

Thompson M. M., Chaovanalikit A. (2003) - Preliminary observations on adaptation and nutraceutical values of Blue Honeysuckle (Lonicera caerulea) in Oregon, USA. Acta Hort., 626: 65-72.

USDA, ARS, National Genetic Resources Program. Germplasm Resources Information Network - (GRIN) [Online Database]. National Germplasm Resources Laboratory, Beltsville, Maryland. [online] http://www.ars-grin.gov/cgi-bin/ npgs/html/taxon.pl?405433 (accessed on 11 October 2011). 


\title{
WPLYW OWADÓW ZAPYLAJĄCYCH NA OWOCOWANIE DWÓCH ODMIAN Lonicera caerulea L.
}

\author{
Bożek M.
}

\author{
S t r e s z c z e n i e
}

W latach 2004, 2006-2008 prowadzono badania nad wpływem owadów zapylających na wiązanie oraz wykształcenie owoców i nasion dwóch odmian suchodrzewu Lonicera caerulea (Sevast.) Pojark.: "Atut" i "Duet". Doświadczenia prowadzono w Polsce południowo-wchodniej - w Gospodarstwie Doświadczalnym Uniwersytetu Przyrodniczego w Lublinie. Kwiaty dostępne dla owadów zapylających przez cały okres kwitnienia wiązały owoce w bardzo wysokim procencie - średnio z lat 90,57\% dla "Duet" i 88,08\% dla "Atut". Natomiast podczas samozapylenia pod izolatorem procent kwiatów wydających owoce był niski i w przypadku "Atut" wynosił średnio 9.37\%, a dla "Duet" 23,85\%. Owocostany powstałe z kwiatów izolowanych miały średnio o 45-50\% mniejszą masę niż zawiązane $\mathrm{z}$ kwiatów dostępnych dla owadów zapylających. Stwierdzono istotny wpływ sposobu zapylania na liczbę nasion wytwarzanych w owocostanach. Przeprowadzone badania wykazują korzystny wpływ owadów zapylających na jakość i masę plonu oraz potwierdzają konieczność zakładania kilkuodmianowych plantacji Lonicera caerulea.

Słowa kluczowe: Lonicera caerulea, suchodrzew, zapylanie, owocowanie. 